\title{
ESP for Ceramic Artists: Exploring the Demonstrative Artist Talk Genre
}

\section{Mark Hammond \\ Kanazawa University}

\section{Reference Data:}

Hammond, M. (2020). ESP for ceramic artists: Exploring the demonstrative artist talk genre. In P. Clements, A. Krause, \& R. Gentry (Eds.), Teacher efficacy, learner agency. Tokyo: JALT. https://doi.org/10.37546/JALTPCP2019-28

By exploring the spoken genre of demonstrative artist talk, or demo, this study is an initial step of an ongoing project to support and train Japanese ceramic practitioners to use English as a foreign an ongoing project to support and train Japanese ceramic practitioners to use English as a foreign component of ceramic arts education, these artist talks combine live hands-on demonstration with simultaneous commentary, for the purpose of sharing technical knowledge and creative processes. Borrowing from methodologies employed in research of a similar genre (architecture student critiques), the current study uses qualitative coding to unpack the discourse of nine talks given at the international conferences of the National Council on Education for the Ceramic Arts. By identifying five salient levels of communicative functions, the analysis provides a point of departure for the development of pedagogical approaches to be implemented at universities and colleges of the arts in Japan.

本研究は、実演的な作家ト一ク (゙゙モ)という話しことばのジャンルを探求することで、陶芸分野の国際社会での実際の場面 で、日本の陶芸従事者が外国語としての英語を使えるようにサポート・訓徚するプロジェクトの最初の一歩とするものである。 この作家ト一つとは、陶芸教育のでく普通の一要素で、技術的知識と創作的過程を共有9る目的をもつて、生の実演とその同 時進行のコメントを結じけるものである。類似のジャンル(建築学生の批評)の研究て使われる方法論を借用して、この研究

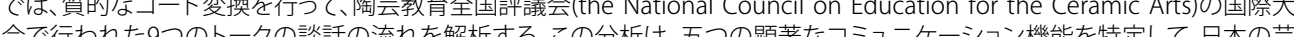

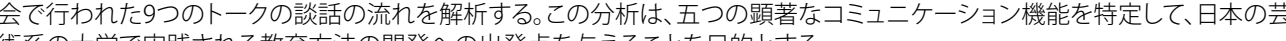
術系の大学で実践される教育方法の開発への出発点を与えることを目的とする n many parts of the world, traditional craft industries are in decline, which in turn - negatively affects the sustainability of local economies and culture. To partially address this problem in Japan, government ministries and agencies have implemented programs and policy aimed at the international promotion of traditional crafts such as ceramics, textiles, metalwork, and lacquerware. The goals of many such programs focus on increasing awareness and interest not only in craft products but also in the dento kogei (伝統工芸) heritage of the creative processes of traditional craft. These programs include the Cool Japan initiative (Ministry of Economy, Trade and Industry, 2017), participation in international design salons by DENSAN-Association for the Promotion of Traditional Craft Industries (DENSAN, 2016), and the membership of Japanese municipalities in the UNESCO Creative Cities Network (UNESCO, 2019). Despite such moves towards international promotion, there has been little consideration of ways to assist Japanese artists and craft practitioners to overcome language barriers that may limit meaningful and direct participation in international contexts. Moreover, in the field of English for specific purposes (ESP), there is a lack of research related to the studio practice of art in general, and there appear to be no studies centered on traditional craft mediums, apart from the author's previous research (Hammond, 2018). Such a gap in the literature makes it difficult to develop pedagogical approaches to prepare Japanese craft professionals to use English as a foreign language in authentic contexts of the international discourse communities related to creative industries.

The study presented in this paper is a step towards addressing this gap in ESP research by focusing on the language needs of potters, clay sculptors, and ceramic artists in higher educational contexts. Specifically, the spoken genre of demonstrative artist talk, often simply referred to as demos, is the study's central focus. Presented here is a preliminary sketch of this genre as practiced by native level speakers of English by identifying salient patterns of communicative functions found in talks given at international conferences in North America. The study is part of an ongoing project intending to train members of the Japanese ceramic community to give demonstrative artist talks in English by 
developing pedagogical approaches suitable for implementation at universities and colleges of the arts in Japan.

After presenting an overview of the demo genre, the author reviews some relevant studies of the somewhat similar genre of architecture student critiques, which were useful for forming the analytical approach used in the current study. Subsequently, the methodology and data set used in the analysis are described, followed by a report of key findings, including examples of salient patterns. Throughout the paper the term artist will be used in a broad sense to refer to professional practitioners of the craft of ceramics, which includes similar titles within the discourse community such as potter, craftsperson, ceramist, clay artist, and ceramic artist. Additionally, the terms demonstrative artist talk, demo, and talk will be used interchangeably.

\section{The Demonstrative Artist Talk Genre}

Demos, often given at international conferences, guest lectures, and artist-in-residency programs, are pedagogical monologues that combine live hands-on demonstration with simultaneous commentary, in order to transfer knowledge of materials, procedures, or techniques. Moreover, they allow artists to share personal accounts of creative process and artistic expression. By their nature demos take place either in a ceramic studio or a makeshift one created for the event, so the audience can observe the hands-on activity of the artists. For smaller venues, it may be possible to be seated close enough to see the artist work, but in some cases with larger audiences, a live video is projected on screens to allow details of techniques to be seen. At the annual international conference of the National Council on Education for the Ceramic Arts (NCECA), for example, video projection allows for featured invited artists to demonstrate to hundreds of attendees.

Much like a plenary or keynote speaker at an academic conference, in some contexts, being invited to give a demo is a sign of recognition for making a contribution to the ceramic arts community. NCECA selects conference demonstrators with "high levels of accomplishment and visibility in the field" who have taken original approaches to ceramic creation and show exemplary capacities as "makers, communicators and thinkers" (NCECA, 2014).

\section{Related Literature From ESP Genre Analysis Studies}

There are no studies of spoken genres practiced by the discourse communities of traditional craft mediums. There is, however, some relevant research concerned with genres as practiced in other creative fields. In particular, investigations of oral presentations given by university students majoring in architectural design provided insight to the current study, especially those embedded in student critiques, also known as juries, crits, or reviews.

In an overview of the development of an English for academic purposes (EAP) program for nonnative English speakers, Swales, Barks, Ostermann, and Simpson (2001) analyzed the components of the spoken discourse of studio-work critiques of eight students in the master's program of architecture at an American university. In the study, "various and changing levels of specificity, rationality, and generality" were found in the design presentation component of the critiques (Swales et al., 2001, p. 445). Suggesting that the elements of the cognitive schema of critiques are more interwoven and recursive than those found in more structured genres, the researchers preferred to use the term "levels of treatment" (Swales et al., 2001, p. 445) instead of the more established terms of steps and moves. Three levels were identified: site description, contextualized rationale, and depiction of design. Within each level, common linguistic patterns were found. For example, when describing the site, short utterances with simple syntax were often used along with deictic reference (e.g., this, that, here). Additionally, Morton and O'Brian (2005) identified levels of treatment in undergraduate architectural programs at an Australian university. The study concluded that successful presentations include rhetorical strategies that allow for personal narrative and storytelling in order to help the audience visualize the design.

Although critiques and demos do differ, in that the former are used as instruments of summative assessment, as opposed to the latter, which are primarily pedagogical in nature, there are some similarities between the two. In both cases presenters address members of their discourse community by interweaving explanations of technique and function of their own creative work with accounts of cognitive processes involved in the course of producing it. Both genres also leave room for the speaker to interject narratives of their personal creative journey and identity as an architect or artist. Reviewing the ESP literature focused on architecture critiques was useful for conceptualizing the rhetorical structure of demonstrative artist talks as having similar reoccurring levels of communicative functions as opposed to a more predictable sequence of steps and moves.

\section{Methodology}

The data set for this study comprises segments of spoken text transcribed from NCECA's Demonstrating Artist DVD Series, which features videos of talks given at the organization's international conferences from 2003 to 2016. Based on the general balance in gender of artists featured in the series, demos by five female and four male 
artists were chosen. Additionally, because the video series encompasses an international community of artists, the selection included six native speakers of English (American) and two nonnative speakers (of Danish and Japanese nationality) who, based on the author's observation, had sufficient spoken fluency to communicate at a comparable level to the native-speaking artists. All demonstrators were mid- to late-career artists whose work has been widely exhibited.

Videos in the series are generally organized into two parts: a prerecorded interview accompanied by still photographs and live hands-on demonstration segments focusing on specific tasks, for example, putting handles on a teapot. For each video, a single segment from the demonstration section was transcribed. As the length of time and volume of spoken discourse varied, segments were selected that were between 15 to 25 minutes long with approximately 125-150 utterances (i.e., sentences, phrases, and words marked by a clear pause), for consistency. This resulted in a total of 1,114 utterances. Each utterance was qualitatively coded based on its communicative function, which will be referred to henceforth as level of treatment, borrowing from the term used by Swales et al. (2001) in their analysis of architectural design critiques. Subsequent to the preliminary analysis, a review of coding was made in order to consolidate similar codes into general levels, which in turn were coded into sublevels.

\section{Levels of Treatment in NCECA Demonstrating Artists Series}

Based on the qualitative coding of all nine transcripts, five salient levels of treatment emerged: procedures, creative processes, general practice, personal narrative, and metadiscourse. Predictably, as it refers to technical actions in the moment, procedures was the most prevalent level at $47 \%$ of all utterances, but there was a substantial presence of the creative processes $(22 \%)$ and the general practice $(16 \%)$ levels. Figure 1 shows the distribution of each level as found in all nine transcripts.

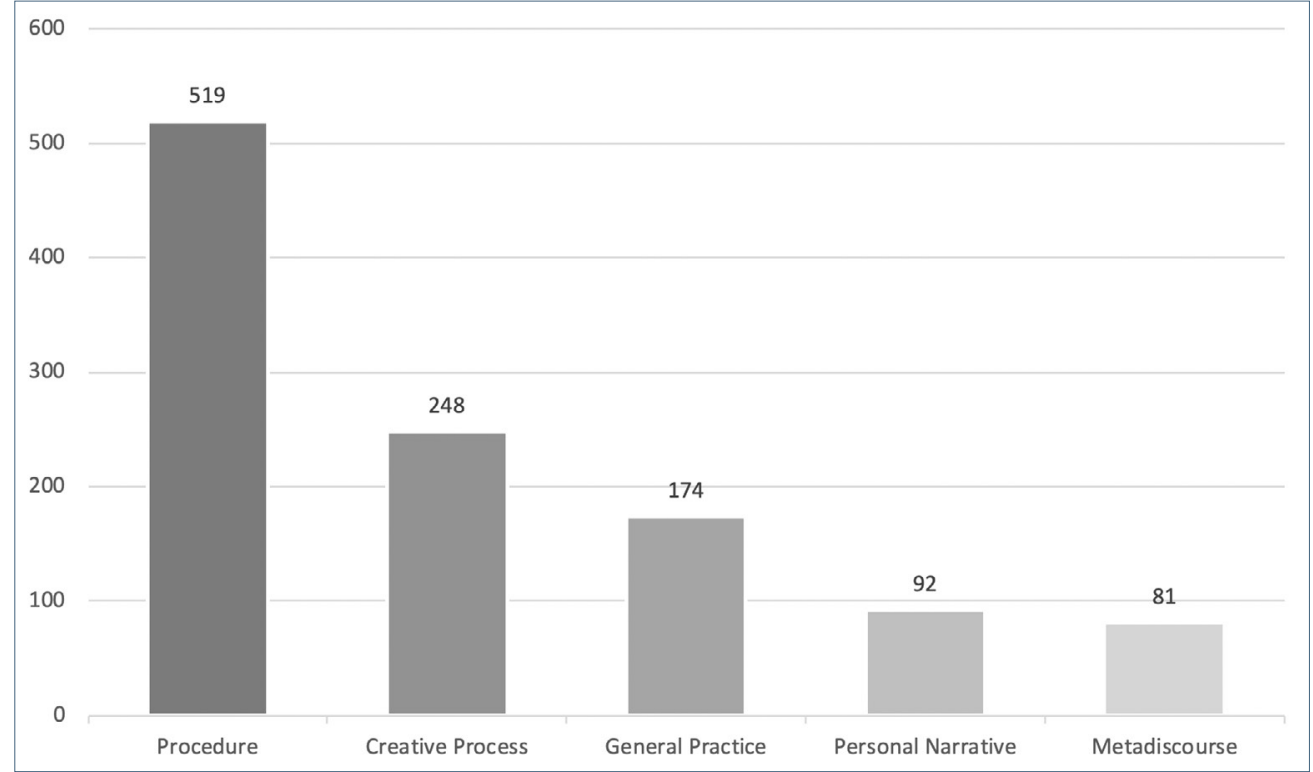

Figure 1. Occurrence of levels of treatment in NCECA demonstrations. Values represent the number of utterances for each level of treatment, as found in a total of 1,114 utterances taken from nine demonstrations.

\section{Procedure Level of Treatment}

Utterances were coded under the category of procedure if they related to specific technical processes of the targeted goal of the demonstration as it unfolded in real time. Common linguistic features of this level included demonstratives as the head noun (e.g., this, that, these, those) and as modifiers (e.g., this tool, these plates) and the use of present and present continuous tense. Classification of sublevels included real-time description of hands-on technique; sequential steps of procedures; describing materials, tools, and equipment; offering a rationale for justifying technique; and describing alternative methods to procedures. Table 1 shows examples of these sublevels. 
Table 1. Sublevels of the Procedure Level of Treatment

\begin{tabular}{ll}
\hline \multicolumn{1}{c}{ Sublevels } & \multicolumn{1}{c}{ Examples } \\
\hline $\begin{array}{l}\text { Hands-on technique } \\
\text { Sequential steps }\end{array}$ & $\begin{array}{l}\text { Using my thumb, I am pushing this, this area inward. } \\
\text { I'm going to make the bodies of my forms and then later I'm } \\
\text { going to put handles and spouts on my forms to finish them. } \\
\text { I use this hard-wired tool and score and slip simultaneously. } \\
\begin{array}{l}\text { Materials, tools, } \\
\text { Rationale }\end{array} \\
\text { Alternative methods }\end{array}$ \\
\hline
\end{tabular}

\section{Creative Processes Level of Treatment}

Utterances that made reference to how the demonstrator thinks in terms of creativity, artistic expression, and the cognitive aspects of making ceramic works were coded as creative processes. Verbs such as think, realized, sense, and feel, as well as the nouns idea, thought, concept, and intention were often employed at this level. Subclassifications, as listed in Table 2, included references to lessons learned; cognitive processes; materials, tools and technique; creative sequence; and form.
Table 2. Sublevels of the Creative Processes Level of Treatment

\begin{tabular}{cl}
\hline Sublevels & \multicolumn{1}{c}{ Examples } \\
\hline Lessons learned & $\begin{array}{l}\text { And then eventually it was like why not just make something } \\
\text { on slabs. }\end{array}$
\end{tabular}
on slabs.

But I guess after you do some of these things long enough you don't need to do that.

Cognitive processes And so that is how my brain thinks, let's finish it all now. And so this feels comfortable to me.

I like to make pottery that I myself want.

It's like having two jobs, and you have to have two brains when you're working with it, with both functional and sculptural work.

Reference to materials, So in a sense it all goes back to a very basic pottery technique of tools, or technique just making a cylinder to create and expand that form.

So I like to use different kinds of clay to give me more options.

Creative sequence And so usually this is my starting point.

Then, I'll make an observation about these plaster slabs. Then I go back to the wheel and continue working on it.

Reference to form But um, so I'm thinking OK, I want it to be this shape, but it's not. But some of the most profound things can be a very small intimate form.

Then I realize that now I need to throw it taller or wider.

\section{General Practice Level of Treatment}

The third most frequently occurring level, general practice, comprised descriptions of how the artists typically work in their studios, including regular patterns or routines unrelated to the actual task being demonstrated. In other words, the level was concerned with the procedures of making, but not with what the audience could witness in real time. At this level, adverbs of frequency (e.g., usually, often, sometimes) were commonly found. Subclassifications, as shown in Table 3, included describing work routines, tendencies, studio characteristics, how technique was developed, and expressing a rationale for procedures. 
Table 3. Sublevels of the General Practice Level of Treatment

\begin{tabular}{|c|c|}
\hline Sublevel & Examples \\
\hline \multirow[t]{2}{*}{ Work routine } & When I throw a cup, I usually throw at least 30 at a time. \\
\hline & $\begin{array}{l}\text { Usually in my studio, on a daily basis when I am making pots, } \\
\text { I'll start off and make a few smaller items. }\end{array}$ \\
\hline \multirow[t]{2}{*}{ Tendencies } & I tend to do my sprig decoration at leather hard. \\
\hline & Usually, in my studio, I work in porcelain. \\
\hline \multirow[t]{3}{*}{ Studio characteristics } & $\begin{array}{l}\text { I actually have an employee in the studio who makes these all } \\
\text { day. }\end{array}$ \\
\hline & I work on a Formica table so I can use the top of that. \\
\hline & In my workshop I have shelves, which I can hang these. \\
\hline \multirow[t]{2}{*}{ Technique development } & I used to have this elaborate process of blow-drying my pots. \\
\hline & $\begin{array}{l}\text { When I first started making these, I was getting all these } \\
\text { cracking problems. }\end{array}$ \\
\hline Rationale & I found out if I painted it, it takes less time to clean up. \\
\hline
\end{tabular}

Personal Narrative Level of Treatment

At the personal narrative level, coding was based on utterances involving anecdotes, storytelling, and description of personal experiences. Table 4 provides examples, including how artists talked about their education, relationships with other artists, stories about home life, and health issues such as having back problems.
Table 4. Sublevels of Personal Narrative Level of Treatment

\begin{tabular}{|c|c|}
\hline Sublevels & Examples \\
\hline \multirow[t]{2}{*}{ Education history } & I visited a lot of factories when I was in graduate school. \\
\hline & As a master's class student at Pennland School, I first tried this. \\
\hline \multirow[t]{2}{*}{$\begin{array}{l}\text { Relationships with other } \\
\text { artists }\end{array}$} & $\begin{array}{l}\text { I worked with John Glick for a year, and it was a very } \\
\text { formidable experience for me. }\end{array}$ \\
\hline & Ok, this is my tribute to Matt Long. \\
\hline \multirow[t]{2}{*}{ Home life } & $\begin{array}{l}\text { Now my wife won't let me do that because it makes the house } \\
\text { smell bad. }\end{array}$ \\
\hline & $\begin{array}{l}\text { At our house we buy honey in bulk, so I made a vessel to pour } \\
\text { honey. }\end{array}$ \\
\hline Health issues & $\begin{array}{l}\text { Starting to reach that point when I am beginning to have back } \\
\text { episodes. }\end{array}$ \\
\hline
\end{tabular}

\section{Metadiscourse Level of Treatment}

A fifth and final level of treatment involves metadiscourse related to the act of demonstration and comprises three sublevels. The first and most prevalent is managing audience comprehension. As described by Ädel (2010), this function may be used by a speaker to confirm the status of listeners' comprehension or to check that communicative channels are not hindered. As the NCECA demonstrations depend primarily on live video projected on large screens out of the view of the artist, most instances of managing comprehension focused on what the audience was actually seeing. A second sublevel, describing technical limitations, involves comparing the physical conditions of the demonstration venue to the artist's usual workplace, such as the difference in clay provided by the organizers or the lack of tools or equipment available at hand. The third sublevel centers on expressing anxiety, such as being nervous while speaking in front of a large audience or worrying about time constraints. Table 5 provides examples of these three subclassifications. 
Table 5. Sublevels of the Metadiscourse Level of Treatment

\begin{tabular}{ll}
\hline Sublevels & Examples \\
\hline $\begin{array}{l}\text { Managing audience } \\
\text { comprehension }\end{array}$ & $\begin{array}{l}\text { You can see on the screen what I am doing, right? } \\
\text { Here, let me move this so you can see it better. } \\
\begin{array}{l}\text { Describing technical } \\
\text { limitations }\end{array} \\
\text { Expressing anxiety }\end{array}$ \\
\hline
\end{tabular}

It is worth noting that although all talks were recorded live and unrehearsed, there was some postproduction editing. It is possible that some utterances aimed at managing audience comprehension were edited out if they were not embedded within other levels.

\section{Discussion and Implications for Further Research}

Keeping in mind that the study was undertaken as an initial investigation of the demo genre, it is important to acknowledge that there are some limitations to the analysis. One is that the qualitative coding of levels was made by the author acting as a single rater, without any outside evaluation of reliability. The inclusion of additional raters, especially ones familiar with the ceramic arts, may have produced richer and more valid results. Another limitation is that the data set of the study only encompasses the spoken discourse of talks delivered at NCECA conferences. It is possible that demos given in other contexts may have different characteristics. For example, it is feasible that talks given at an artist's own studio or at smaller venues may not require the same amount of metalanguage typically used at large conferences. Future research, encompassing a fuller range of contexts, may help to address this issue.

Notwithstanding these limitations, the findings have implications for future research that may support the project's goal of developing a valid pedagogical approach to training Japanese artists to give talks in English. First, they provide a preliminary framework to design an ESP course suitable for higher education of the ceramic arts in Japan. In such a course, syllabus and lesson planning focused on one level at a time may help to simplify the multidimensional communicative functions present in the genre.

Secondly, the results can also be used as a resource to develop learning materials that incorporate authentic lexical items used in each specific level and sublevel. This may be achieved in future studies by using corpus-based tools to analyze the text of the NCECA videos or similar talks to determine which words and phrases are most frequently used. Furthermore, the levels of treatment found in the study may be employed in classroom tasks that call on learners to view segments of the videos and code utterances by themselves. Such activities can raise awareness of the linguistic characteristics of each level, which in turn may foster learners' ability to produce similar language in talks of their own.

Finally, the identified levels of treatment provide a point of departure for the logical next step of conducting comparative analyses of case studies of talks given by Japanese artists in English. By building on the methodology of the current study, it may be possible to identify what particular levels or other factors are most problematic for those who aspire to use English as a foreign language to interact with the international community of ceramic arts.

\section{Conclusion}

The purpose of the study, rendering a preliminary sketch of the demo genre, was successfully achieved to some degree. Borrowing the concept of integrated communicative levels of treatment from research literature focused on ESP in architecture student critiques, the author identified five salient levels in talks given at large international conferences: procedure, creative process, general practice, personal narrative, and metadiscourse. Additionally, each level was further categorized into several sublevels based on communicative function or theme, which provide a more detailed look at the rhetorical structure of talks by members of the international discourse community. Although the study's methodology produced a limited analysis, the results are useful as a preliminary guide for further research that may advance the project's goal of developing an approach to train Japanese artists to give demonstrative talks in English in authentic contexts with their international peers.

\section{Acknowledgments}

This research was funded by The Japan Society for the Promotion of Science (Kaken Grant-in-Aid for Scientific Research-C 19K00758).

\section{Bio Data}

Mark Hammond is an associate professor at Kanazawa University, Institute of Liberal Arts and Sciences, Faculty of Foreign Language Studies, and also the director of a selfaccess program, the English Help Center, at Kanazawa College of Art. 


\section{References}

Ädel, A. (2010). "Just to give you kind of a map of where we are going": A taxonomy of

metadiscourse in spoken and written academic English. Nordic Journal of English Studies, 9(2), 6997. https://doi.org/10.35360/njes.218

DENSAN. (2016). DENSAN-The Association for the Promotion of Traditional Craft Industries will be exhibiting at the Milan Design Week 2016 [Press release]. Retrieved from

http://www.densan-world.jp

Hammond, M. (2018). Using discourse analysis to develop L2 learning materials for hands-on creative-tourism workshops. OnCUE Journal, 11(2), 123-130. Retrieved from https://jaltcue.org

Ministry of Economy, Trade and Industry. (2017, March 8). METI releases concept book: A compilation of traditional Japanese value as the foundation of commodities and services under the Cool Japan Initiative. Wonder Nippon! [Press release]. Retrieved February 24, 2020, from https://www.meti.go.jp/english/press/2017/0308_001.html

Morton, J., \& O’Brian, D. (2005). Selling your design: Oral communication pedagogy in design education. Communication Education, 54(1), 6-19. https://doi.org/10.1080/03634520500076885

NCECA. (2014). Presentation deadlines for demonstrating artists. Retrieved from

https://nceca.net/2104-presentation-deadlines/

Swales, J., Barks, D., Ostermann, A., \& Simpson, R. (2001). Between critique and accommodation: Reflections on an EAP course for masters of architecture students. English for Specific Purposes, 20(Suppl.1), 439-458. https://doi.org/10.1016/S0889-4906(01)00020-5

UNESCO. (2019). Voices of the city: UNESCO creative cities moving towards the 2030 agenda for sustainable development [Booklet]. Retrieved from https://en.unesco.org/creative-cities/sites/ creative-cities/files/16_pages_villes_creatives_uk_bd.pdf 